\title{
Peran Masyarakat dan Swasta dalam Pengelolaan Sampah di Kota Kecil Jawa Tengah (Studi Kasus: Kawasan Kupang Kidul, Kota Ambarawa)
}

\author{
Reni Astuty Manurung1 \\ Kementerian Pekerjaan Umum \\ DKI Jakarta, Indonesia
}

\begin{abstract}
Abstrak: Kota kecil memiliki peranan yang strategis dalam konteks pengembangan wilayah. Peranan kota kecil sangat erat kaitannya dengan konsep growth pole dan teori tempat pusat Christaller. Secara umum peranan kota kecil dalam pengembangan daerah perdesaan memiliki tiga peranan pokok yaitu sebagai pusat perdagangan, pusat penyerapan tenaga kerja, dan sebagai pusat pelayanan (Bajracharya: 2000, Mathur: 1982). Sedangkan dalam konteks sistem perkotaan, peranan kota lebih dilihat dari segi skala pelayanan masing-masing kota. Kota kecil dapat berkembang sebagai pusat pelayanan regional sedangkan lainnya merupakan pusat pelayanan lokal. Tata kelola adalah rangkaian proses, kebiasaan, kebijakan, aturan, dan institusi yang mempengaruhi pengarahan, pengelolaan, serta pengontrolan suatu perusahaan atau korporasi. Pemerintah sebagai petinggi daerah selalu menjadi aktor utama dalam tata kelola kota kecil. Namun, tanpa disadari keberadaan swasta dan masyarakat memiliki peran penting dalam keberhasilan penataan dan pengelolaan kota kecil. Permasalahan sampah merupakan salah satu sektor yang diperhatikan dalam upaya adaptasi suatu kota untuk mencapai kota yang berketahanan. Undang-Undang No. 18 Bab IX Pasal 28 ayat (1) menjelaskan peran masyarakat dalam pengelolaan sampah yang diselenggarakan oleh pemerintah dan/atau pemerintah daerah. Kecamatan Ambarawa adalah sebuah kota pasar yang terletak di lingkaran segitiga antara Semarang, Solo, dan Jogjakarta. Permasalahan yang dihadapi Ambarawa pada sistem perkotaan adalah kurang optimalnya bentuk dan peran masyarakat dan swasta dalam penataan dan pengelolaan perkotaan, salah satunya adalah pengelolaan sampah perkotaan. Tujuan dari penelitian ini adalah mengetahui bagaimana swasta dan masyarakat berperan dalam pengelolaan sampah perkotaan, khususnya pada perkotaan kecil di Jawa Tengah, dengan studi kasus kawasan Kupang Kidul, Kota Ambarawa. Terdapat dua sasaran yang akan dicapai yaitu (1) mengidentifikasi siapa aktor dalam pengelolaan sampah di Kota Ambarawa; dan (2)menganalisis bagaimana aktor tersebut berperan dalam pengelolaan sampah di Kota Ambarawa. Metode yang digunakan dalam penelitian ini adalah metode campuran (mixed method) antara kualitatif dan kuantitatif. Penelitian ini akan menggunakan metodologi studi kasus (case study) sebagai strategi penelitian (strategy of inquiry) utama. Teknik pengumpulan data dilakukan dengan observasi lapangan, wawancara swasta dan masyarakat, kuesioner check-list masyarakat, serta menelaah dokumen dari survei instansi. Sedangkan teknik analisisnya menggunakan statistik dekriptif, dengan analisis deskriptif kuantitatif dan kualitataif, serta analisis skoring. Hasil observasi mengenai pengelolaan sampah di kawasan Kupang Kidul sudah melibatkan masyarakat dan swasta dalam peranannya. Namun untuk peran swasta masih sangat minim sehingga masyarakat di kawasan Kupang Kidul masih mengalami beberapa kendala dalam pengelolaan sampah khususnya peran sebagai penyedia dana. Selain itu, masih sedikit pihak
\end{abstract}

\footnotetext{
${ }^{1}$ Korenspondensi Penulis: Kementerian Pekerjaan Umum, DKI Jakarta Email: rhenii1815@gmail.com
} 
swasta yang menganggap bahwa sampah di kawasan tersebut perlu untuk dikelola. Pihak swasta yang sudah terlibat masih secara perorangan.

Kata Kunci: Ambarawa, kota kecil, masyarakat, sampah, swasta, tata kelola

\begin{abstract}
Small cities have strategic role in the contect of regional development. The role of those cities is tightly related to the concept of growth pole and the theory of center place by Christaller. Generally, the role of small cities in village development has 3 basic roles, namely as the center of retail, employment and service (Bajracharya: 2000, Mathur: 1982). But, in the case of urban system, the role of city is identified more from the scale of urban service each cities. Small city can grow as regional service core and the rest can be as local service. Management is a serial of process, habbit, policy, rule and institution which affects direction, management, and control in an enterprise or corporation. Government, as a local high institution, acts as a primer actor in small city management. Nevertheless, the existence of private and community unconsciously has an important role in the success of small city management. Waste problem is one of many sectors that are noticed in effort of city adaptation to achieve a resilient city. The act number 18 IX chapter 28 verse (1) defines about community role in waste management which is conducted by government or local government. Ambarawa sub district is a market city which lies on a triangle-circle among Semarang, Solo, and Jogjakarta. Ambarawa is facing a problem which is the form and role of community that is less optimal in city management, such as city waste management. The purpose of this research is to find out how private and community act in city waste management, particularly in the small cities of central java with case study in Kupang Kidul, Ambarawa City. There are 2 objectives which are to identify who the actor in waste management in Ambarawa and to analyze how the actor acts in waste management in Ambarawa City. This research uses mixed method both quantitative and qualitative. Then, it will be used the methodology of study case as a primary research strategy. Data collection will be carried out by field observation, private and community interview, questionnaire, and document from secondary survey. Beside, analysis technique uses descriptive statistic, with quantitative and qualitative descriptive and scoring analysis. Observation result from this research is that waste management in Kupang Kidul has involved community and private. Nevertheless, private role is scarce so that community has difficulty and problem in waste managemen, especially in case of providing funds. Besides that, there is still a small number of private which considers that waste in the site needs to be managed well. Private sector is still involved individually.
\end{abstract}

Key Words: Ambarawa, community, management, private, small city, waste

\title{
Pendahuluan
}

Pengertian urbanisasi sudah umum diketahui oleh mereka yang banyak bergelut di bidang kependudukan, khususnya mobilitas penduduk. Namun demikian, mereka yang awam dengan ilmu kependudukan sering kali kurang tepat dalam memakai istilah tersebut. Dalam pengertian yang sesungguhnya, urbanisasi berarti persentase penduduk yang tinggal di daerah perkotaan. Sedangkan mereka yang awam dengan ilmu kependudukan seringkali mendefinisikan urbanisasi sebagai perpindahan penduduk dari desa ke kota. Padahal perpindahan penduduk dari desa ke kota hanya salah satu penyebab proses urbanisasi, di samping penyebab-penyebab lain seperti pertumbuhan alamiah penduduk perkotaan, perluasan wilayah, maupun perubahan status wilayah dari daerah pedesaan menjadi daerah perkotaan, dan semacamnya itu.

Fenomena urbanisasi sangat jelas terlihat di negara-negara sedang berkembang, termasuk Indonesia. Fenomena tersebut tidak sepenuhnya terjadi pada kota-kota besar 
(mega-urban region) tetapi juga pada kota-kota kecil atau disebut juga urbanisasi in-situ. Urbanisasi pada mega-urban region, seperti Jakarta, jelas menimbulkan masalah dan issues perkotaan yang sampai saat ini masih belum ketemu titik terang penyelesaiannya. Permasalahan urbanisasi yang terjadi pada mega-urban region dapat dijadikan suatu fokus penelitian guna menemukan win-win solution bagi para urbanis. Tidak jauh berbeda dengan urbanisasi mega-urban region, urbanisasi in-situ juga terjadi sebagai fenomena munculnya urbanisasi pada kota-kota kecil. Hal ini jelas menjadi masalah bagi kota-kota kecil yang menjadi tujuan dari para urbanis.

Perkembangan perkotaan di Indonesia cenderung mengarah kepada terbentuknya kawasan perkotaan yang semakin membesar dan terintegrasi. Kondisi tersebut terlihat dari semakin luasnya daerah yang menunjukkan ciri fisik perkotaan di kawasan suburban yang telah menyatu dengan kota intinya, dimana proses pengkotaan yang terjadi di pinggiran kota besar terjadi lebih cepat dibanding yang terjadi di kota besar itu sendiri. Adanya fenomena tersebut mengakibatkan terjadinya proses transformasi ruang dan sosioekonomik wilayah kota-kota menengah maupun kota-kota kecil di sekitarnya sebagai akibat dari proses modernisasi dan industrialisasi kota besar (inti), dimana pada akhirnya mengakibatkan perkembangan kota-kota tersebut terkesan menyatu (Sugiana, 2005: 42). Menyatunya kota-kota tersebut pada akhirnya mengakibatkan terjadinya fenomena wilayah perkotaan yang sangat besar (mega-urban regions), seperti halnya yang terjadi di kota-kota megapolitan seperti Kota Jakarta dengan kota-kota kecil di sekitarnya (Jabodetabek), dimana kota megapolitan tersebut berperan sebagai inti (Firman dan Tjahjati, 2005: 87).

Faktanya di Indonesia, sebagaimana yang diungkapkan dalam UN Population Division (2007), pada 2000 jumlah penduduk perkotaan yang bertempat tinggal di kotakota kecil dengan ukuran kurang dari 500.000 jiwa adalah sebanyak 68\% dari jumlah populasi perkotaan secara keseluruhan. Pertambahan penduduk perkotaan telah menjadi bagian dalam globalisasi yang kehadirannya tidak dapat disekat-sekat lagi (Suara Merdeka, Maret 2012). Oleh karena itu, yang terpenting dalam menangani masalah urbanisasi adalah bagaimana membuat kebijakan perkotaan agar dapat mengadaptasi potensi-potensi menguntungkan bagi perkembangan perkotaan yang sebagian memang masih miskin.

Permasalahan yang ada di kota-kota kecil dapat disebabkan dari berbagai aspek dan perspektif. Data sensus juga menunjukkan bahwa laju perkembangan penduduk perkotaan pada kota-kota kecil di Indonesia lebih tinggi dibandingkan dengan laju pertumbuhan penduduk pada kota-kota besar. Salah satu perspektif yang dapat diangkat adalah mengenai tata kelola kota kecil jika dilihat dari peran swasta dan masyarakat. Seberapa besar dampak atau pengaruh keberadaan swasta dan masyarakat dalam tata kelola kota kecil dapat dilihat pada salah satu kota kecil yang ada di Jawa Tengah, yaitu Ambarawa (lihat Gambar 1).

Permasalahan sampah merupakan salah satu sektor yang diperhatikan dalam upaya adaptasi suatu kota untuk mencapai kota yang berketahanan. Pengelolaan sampah yang ada di Indonesia saat ini dianggap kurang efektif dan cenderung merusak lingkungan sehingga tidak mengarah pada pembangunan berkelanjutan yang seharusnya dicanangkan di tiap-tiap kota di Indonesia. Pengelolaan sampah yang dilakukan saat ini di Indonesia hanya mengandalkan upaya pembuangan sampah yang dilakukan secara open dumping dengan umur pakai terbatas.

Tidak semua upaya untuk peningkatan yang dilakukan untuk mengatasi sanitasi limbah padat berhasil. Beberapa inisiatif hanya mengandalkan banyak investasi modal dalam teknologi dan terbukti mengecewakan. Namun, terdapat pendekatan baru yang sedang berkembang. Saat ini lebih banyak perhatian diberikan kepada alternatif penyedia layanan, khususnya kelompok masyarakat, sektor swasta, dan sektor informal. Pentingnya 


\section{Peran Masyarakat dan Swasta dalam Pengelolaan Sampah di Kota Kecil Jawa Tengah}

partisipasi masyarakat sedang direalisasikan. Hal ini memungkinkan untuk perbaikan ke arah pembangunan berkelanjutan sesuai dengan tujuan dari Millenium Development Goals yaitu fokus pada kebijakan-kebijakan dan upaya-upaya dalam kegiatan yang dapat memberikan manfaat bagi pembangunan berkelanjutan.

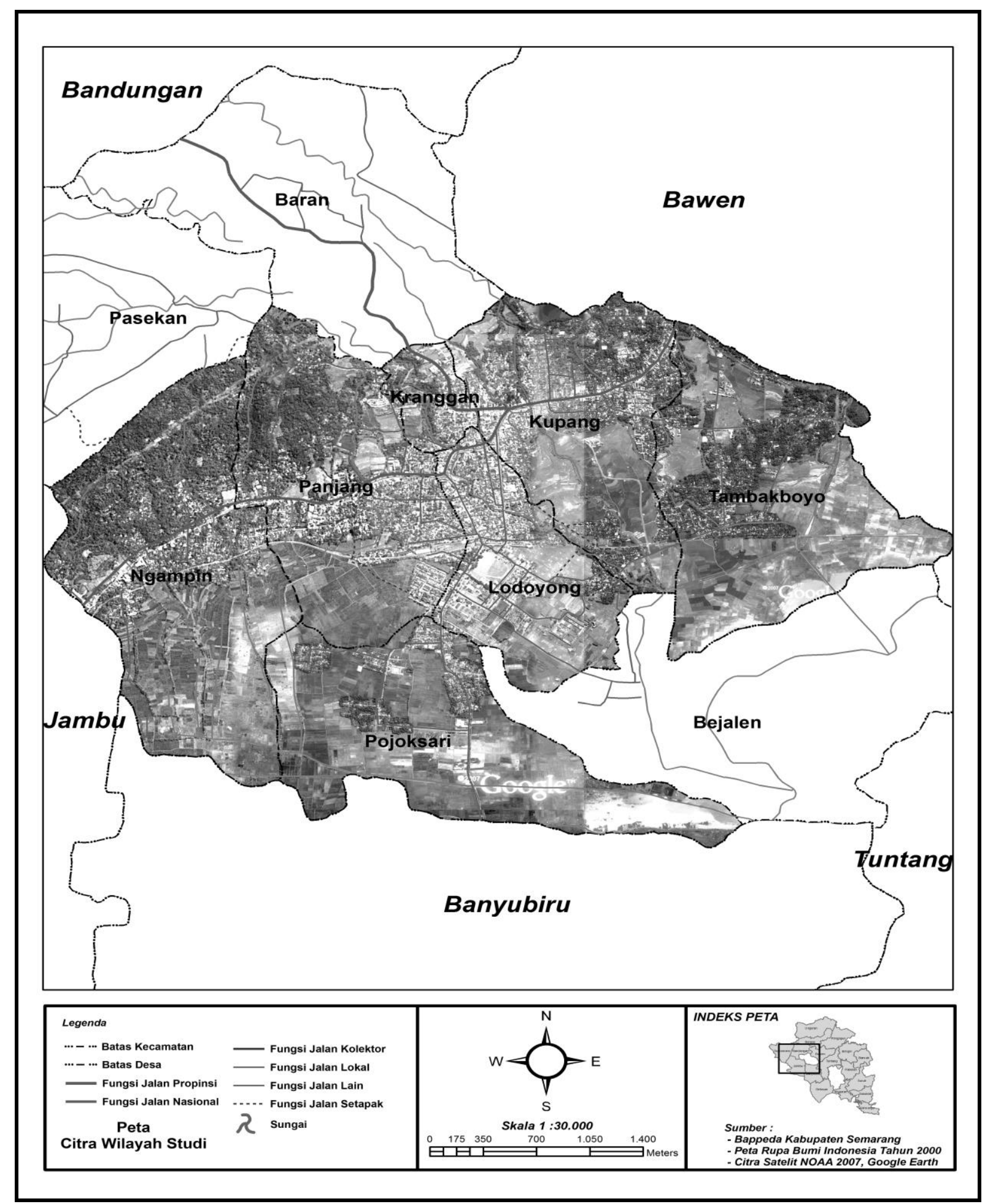

Gambar 1. Peta Citra Kota Ambarawa 
Undang-Undang No. 18 Bab IX Pasal 28 ayat (1) menjelaskan peran masyarakat dalam pengelolaan sampah yang diselenggarakan oleh pemerintah dan/atau pemerintah daerah. Peran sebagaimana dimaksud pada ayat (1) dapat dilakukan melalui pemberian usul, pertimbangan, dan saran kepada pemerintah dan/atau pemerintah daerah; perumusan kebijakan pengelolaan sampah; dan/atau pemberian saran dan pendapat dalam penyelesaian sengketa persampahan.

Berdasarkan permasalahan di atas, dapat disimpulkan bahwa peran swasta dan masyarakat juga menentukan keberhasilan pengelolaan sampah perkotaan. Dengan demikian, timbul pertanyaan penelitian bagaimana peran swasta dan masyarakat terhadap pengelolaan sampah perkotaan di kota kecil Ambarawa. Selanjutnya dapat diidentifikasi bahwa swasta dan masyarakat memiliki andil dalam pengelolaan sampah perkotaan di kota kecil Ambarawa.

Tujuan utama dari penelitian ini yaitu untuk mengetahui bagaimana swasta dan masyarakat berperan dalam pengelolaan sampah perkotaan, khususnya pada perkotaan kecil di Jawa Tengah, dengan studi kasus di Kota Ambarawa. Beberapa sasaran yang ingin dicapai dalam penelitian ini yaitu:

1. Mengidentifikasi siapa aktor dalam pengelolaan sampah di Kota Ambarawa.

2. Menganalisis bagaimana aktor tersebut berperan dalam pengelolaan sampah di Kota Ambarawa.

\section{Tinjauan Teoritis}

\section{Permasalahan Pengelolaan Sampah}

Menurut Kodoatie (2003:219) secara umum persoalan yang muncul pada pengelolaan sampah di daerah adalah sebagai berikut:

1. Aspek kelembagaan

Permasalahan pada aspek kelembagaan ini terkait dengan sumber daya manusia yang kurang memadai dari segi jumlah maupun kualifikasinya. Selain itu, tidak sesuainya bentuk kelembagaan dengan besarnya kewenangan yang harus dikerjakan.

2. Aspek teknis operasional

Pada aspek teknis operasional, permasalahan yang sering muncul adalah terbatasnya sarana dan prasarana pengumpulan kontainer, pengangkutan, pengolahan di tempat pembuangan akhir, dan lahan untuk tempat pembuangan akhir, serta penanganan akhir.

3. Aspek pembiayaan

Permasalahan pada aspek pembiayaan adalah terkait dengan biaya yang harus dikeluarkan untuk pelaksanaan kegiatan pengelolaan sampah. Misalnya, penarikan retribusi yang kurang memadai.

4. Aspek pengaturan

Tidak dimilikinya kebijakan pengaturan pengelolaan di daerah yang mampu memberikan motivasi kesadaran peran serta masyarakat untuk ikut secara utuh dalam pengelolaan baik menyangkut pembiayaan dan teknis operasional.

5. Aspek peran serta masyarakat

Kurangnya kesadaran masyarakat dalam pengelolaan sampah. Hal ini juga dapat diketahui dari masih sedikitnya masyarakat yang belum dapat mengolah sampah dan mengelolanya dengan baik. 


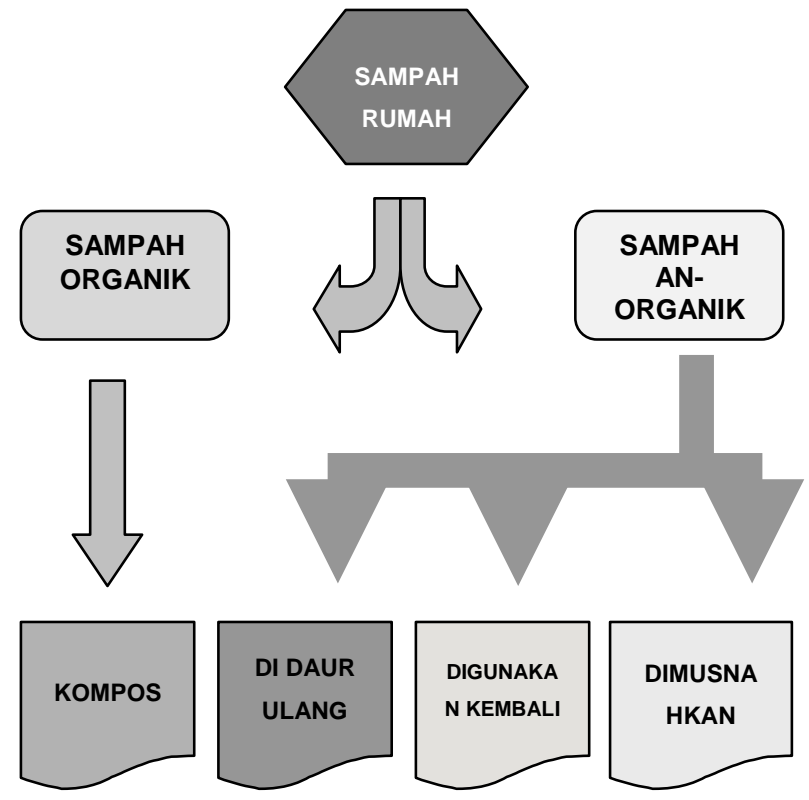

Sumber: SNI 19-2454-2002 Tata Cara Teknik Pengelolaan Sampah Perkotaan

\section{Gambar 2. Sistem atau Model Pengelolaan Sampah Berbasis Masyarakat}

Sedangkan Dukun (2003: 505) menyebutkan bahwa permasalahan pengelolaan sampah terletak pada sistem pengelolaan pada pembuangan akhir. Pembuangan akhir masih banyak yang menggunakan sistem open dumping. Pembuangan sistem open dumping ini sendiri tidak dikelola dengan baik, hanya menjadi timbunan sampah dan tidak adanya penutupan tanah. TPA yang awalnya didesain menggunakan sistem sanitary landfill pun tetap saja dikelola dengan menggunakan sistem open dumping.

Penyebab tidak efisiennya pengelolaan sampah di Indonesia sendiri adalah tidak adanya dukungan dari pemerintah. Pemerintah diharapkan mampu menyelesaikan permasalahan sampah secara sistematis dan menyeluruh. Tidak adanya dukungan penuh dari pemerintah mengakibatkan banyaknya anggapan masyarakat bahwa sungai adalah tempat sampah karena kurangnya pengetahuan masyarakat tentang prosedur dan tata cara pengelolaan sampah. Selain itu, akibat lainnya adalah masyarakat banyak yang mengelola sampah secara konvensional seperti dibakar atau ditimbun ke tanah.

\section{Alternatif Pengelolaan Sampah Perkotaan}

Akar dari permasalahan sampah di perkotaan yang dihadapi oleh banyak negara berkembang adalah peningkatan jumlah timbulan sampah perkotaan. Produksi sampah perkotaan secara bertahap meningkat di kota-kota pada negara berkembang. Di Bangladesh, pada tahun 1995 dihasilkan 0,49 kg/orang/ hari sampah perkotaan Bangladesh yang diperkirakan meningkat menjadi 0,6 kg pada tahun 2025 (Ray, 2008: 5 dalam A crisis in governance: Urban solid waste management in Bangladesh oleh Shahjahan H. Bhuiyan). Di Indonesia sendiri tercatat bahwa pada tahun 2000, dari 384 kota yang menimbulkan sampah sebesar $80.235,87$ ton setiap hari, penanganan sampah yang diangkut ke dan dibuang ke Tempat Pembuangan Akhir (TPA) adalah sebesar 4,2 \%, yang dibakar sebesar 37,6 \% yang dibuang ke sungai 4,9\% dan tidak tertangani sebesar 53,3 \% (BPS, 2010).

Untuk menangani permasalahan sampah secara menyeluruh perlu dilakukan alternatif-alternatif pengelolaan sampah. Alternatif-alternatif pengelolaan sampah yang 
sekarang diperlukan adalah alternatif yang harus bisa menangani semua permasalahan pembuangan sampah dengan cara mendaur-ulang semua limbah agar dapat kembali ke alam atau dibuang dalam bentuk pengembalian ekonomi masyarakat seperti barangbarang tepat guna, sehingga dapat mengurangi tekanan terhadap sumber daya alam. Daripada mengasumsikan bahwa masyarakat akan menghasilkan jumlah sampah yang terus meningkat, minimisasi sampah harus dijadikan prioritas utama.

Sampah yang dibuang harus dipilah, sehingga tiap bagian dapat dikomposkan atau didaur-ulang secara optimal, daripada dibuang ke sistem pembuangan limbah yang tercampur seperti yang ada saat ini. Dan industri-industri harus mendesain ulang produkproduk mereka untuk memudahkan proses daur-ulang produk tersebut. Prinsip ini berlaku untuk semua jenis dan alur sampah. Sedangkan menurut Satyawan (2007:11), untuk menangani permasalahan sampah yang terkait dengan aspek teknis operasional yang disebutkan di atas, diperlukan pengelolaan pada aspek teknis operasional itu sendiri. Aspek ini meliputi sarana pewadahan, pengumpulan, pengangkutan, pengolahan, dan pembuangan akhir. Berikut skema pengelolaan dalam aspek teknis operasional.

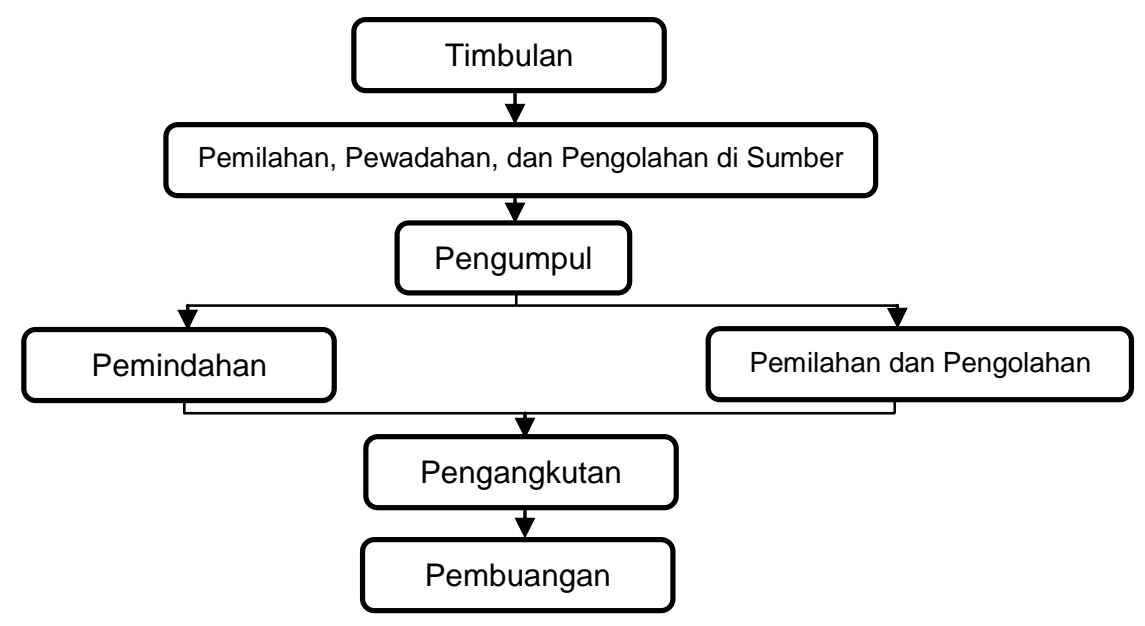

Sumber: SNI 19-2454-2002 Tata Cara Teknik Pengelolaan Sampah Perkotaan

\section{Gambar 3. Skema Teknik Operasional Pengelolaan Persampahan}

Peran serta masyarakat dalam pengelolaan sampah bisa meliputi partisipasi masyarakat dalam pengelolaan lingkungan, membayar retribusi yang telah ditetapkan oleh pemerintah daerah, swadaya dalam pengadaan tong sampah dan gerobak sampah dan sebagainya. Peran serta masyarakat dalam pengelolaan sampah tergantung dari cara pendekatan pemerintah dalam mensosialisasikan program-programnya dalam penanggulangan kebersihan. Memberikan dorongan pada masyarakat agar membiasakan masyarakat pada tingkah laku yang sesuai dengan apa yang telah diprogramkan.

Peran serta masyarakat sangat mendukung program pengelolaan sampah (kebersihan) di suatu kota/wilayah. Peran serta masyarakat menurut Habitat dalam Panudju dalam Irman (2004:50) adalah sebagai berikut:

"Participation is process of involving people; especially those directly effected, to define the problem and involve solutions with them". (Habitat-Citynet; 1997:29)

Partisipasi masyarakat sangat penting di dalam upaya pengelolaan persampahan bertujuan untuk kebersihan dan keindahan kota. Dalam kebijakan manajemen pengelolaan persampahan yang diarahkan oleh Departemen PU, peran serta dan tanggung jawab 


\section{Peran Masyarakat dan Swasta dalam Pengelolaan Sampah di Kota Kecil Jawa Tengah}

masyarakat adalah mulai dari penyediaan pewadahan hingga pengumpulan sampah ke lokasi Tempat Pembuangan Sementara (TPS) atau Transfer Depo, sedangkan pengangkutan sampah dari TPS ke lokasi Tempat Pembuangan Akhir (TPA) merupakan tanggung jawab pemerintah kota/ kabupaten.

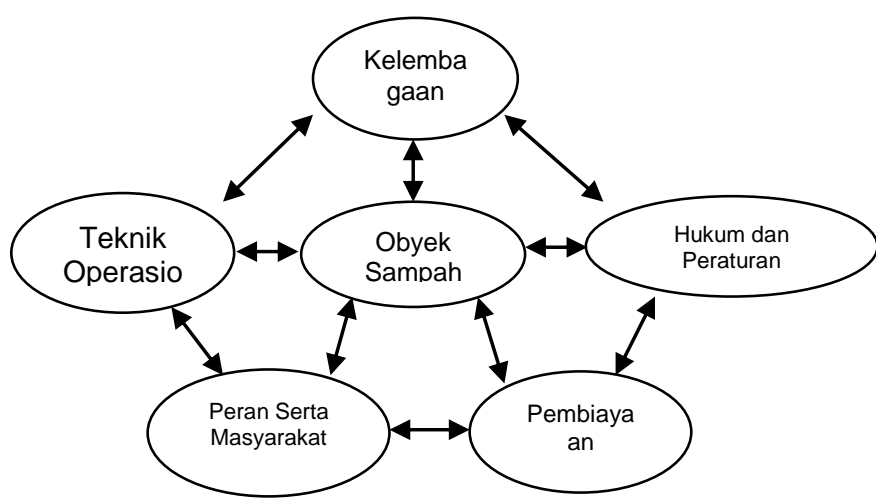

Sumber: SNI 19-2454-2002 Tata Cara Teknik Pengelolaan Sampah Perkotaan

\section{Gambar 4. Skema Manajemen Pengelolaan Sampah Perkotaan}

Dari gambar 4 terlihat bahwa dalam sistem pengelolaan sampah antara aspek teknis operasional, kelembagaan, hukum dan peraturan, pembiayaan, dan peran serta masyarakat saling terkait dan tidak dapat berdiri sendiri. Peran serta masyarakat merupakan salah satu metode terbaru dalam pengelolaan sampah perkotaan. Hal ini diharapkan dapat menjadi solusi terbaik dalam permasalahan sampah untuk pengembangan perkotaan. Selain itu, peran serta masyarakat merupakan sasaran yang tepat dalam pengelolaan sampah perkotaan karena sebagian besar sampah yang menjadi masalah perkotaan berasal dari masyarakat itu sendiri.

\section{Metode Penelitian}

Tahap analisis merupakan tahap penting dalam proses penelitian. Data dan informasi yang didapat dari lapangan, diolah dan diinterpretasikan, serta dianalisis sesuai kebutuhan penelitian. Dari hasil analisis tersebut kemudian diperoleh keterkaitan antarhasil analisis dan dapat digunakan untuk menemukan jawaban atas pertanyaan dan tujuan penelitian.

Teknik analisis yang digunakan untuk melakukan proses analisis adalah analisis deskriptif kualitatif, kuantitatif, dan skoring. Analisis deskriptif kualitatif digunakan untuk mentransformasikan data mentah ke dalam bentuk data yang mudah dipahami serta menyusun dan menyajikannya menjadi informasi yang akurat. Analisis deskriptif kuantitatif menggunakan bentuk bantuan analisis berupa tabel, grafik, maupun diagram. Data tersebut kemudian dideskripsikan guna memperjelas maksud dari tabel, grafik, dan diagram sebagai visualisasi dari proses analisis terhadap bentuk peran masyarakat dan swasta dalam pengelolaan sampah perkotaan di Kota Ambarawa. Selanjutnya, analisis skoring akan digunakan dalam pemberian nilai pada kuesioner. Adapun proses analisis data pada penelitian ini seperti yang divisualisasikan pada Gambar 5. 


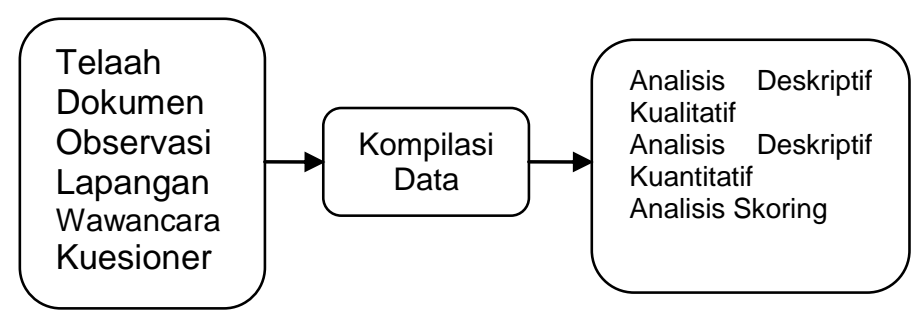

\section{Gambar 5. Diagram Tahapan Teknik Analisis}

Secara lebih jelas dan lengkap teknik analisis yang akan digunakan dalam penelitian ini dapat dilihat dalam kerangka analisis di bawah ini:

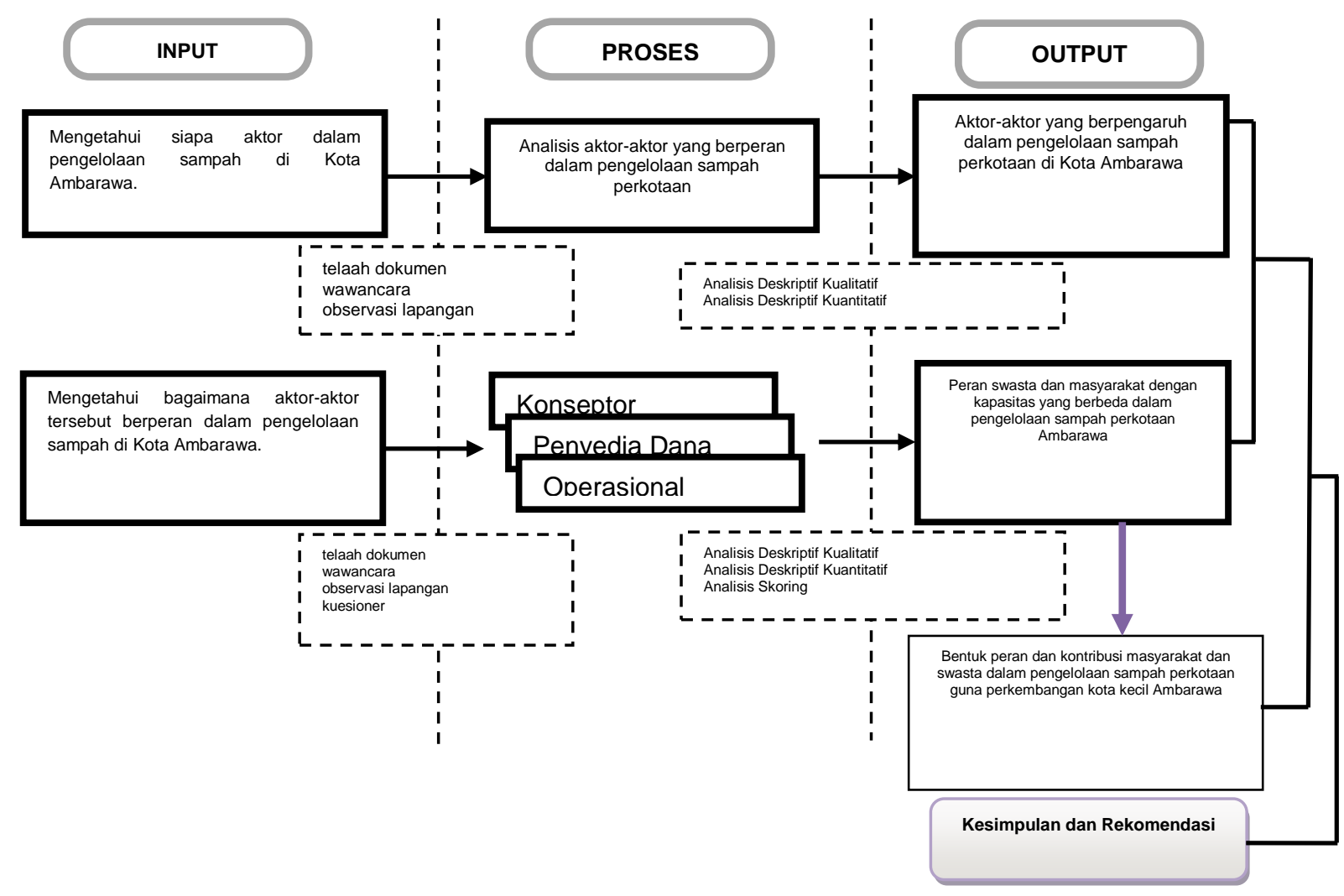

\section{Gambar 6. Kerangka Analisis Penelitian}

Dari kerangka analisis di atas dapat dijelaskan bahwa terdapat tiga teknik analisis yang digunakan dalam penelitian ini. Analisis deskriptif kualitatif dan kuantitatif dominan digunakan dalam penjabaran hasil telaah dokumen, observasi lapangan, dan wawancara guna mempermudah dalam penyajian dan analisis data. Sedangkan untuk analisis skoring digunakan dalam pemberian nilai pada kuesioner sehingga mempermudah peneliti dalam analisis peran aktor dalam pengelolaan sampah perkotaan di Ambarawa sehingga tujuan penelitian dapat dicapai secara maksimal dan tepat sasaran. 


\section{Peran Masyarakat dan Swasta dalam Pengelolaan Sampah di Kota Kecil Jawa Tengah}

\section{Pembahasan}

Aktor yang berkecimpung dalam pengelolaan sampah skala perkotaan memiliki berbagai peran yang berbeda dengan segala kepentingan yang berbeda pula. Hal ini juga dirasakan dalam pengelolaan sampah di Kota Ambarawa khususnya kawasan Kupang Kidul dengan tata guna lahan yang terdiri dari permukiman, perdagangan dan jasa, dan perkantoran. Tidak sedikit aktor yang tergerak untuk berperan dalam pengelolaan sampah meskipun dalam skala mikro yaitu rumah tangga. Peran aktor-aktor tersebut memberi pengaruh positif dalam pengelolaan sampah di kawasan Kupang Kidul sehingga berdampak bagi perkembangan infrastruktur perkotaan Ambarawa.

\section{Peran pada Level/ Aspek Konseptor}

Dari observasi yang didapat di kawasan Kupang Kidul, terdapat dua perbedaan perspektif mengenai peran konseptor yang ada di kawasan tersebut. Untuk kawasan perdagangan dan jasa tepatnya yang berada di sepanjang Jalan Jenderal Sudirman diperoleh bahwa hanya ada satu konseptor yang berperan dalam pengelolaan sampah di Kupang Kidul yaitu Ketua RW. Hal ini dikarenakan beliau dianggap memiliki tanggung jawab untuk mengurusi hal-hal terkait pengembangan kawasan termasuk infrastruktur yaitu pengelolaan sampah. Sedangkan untuk kawasan permukiman yang ada di Kupang Kidul, menyatakan bahwa tidak ada konseptor yang mengurusi pengelolaan sampah dikarenakan sepenuhnya diserahkan kepada masyarakat.

Sebagian besar para pedagang baik pedagang dengan pertokoan besar, sedang, dan kecil menyerahkan pengelolaan sampah dagangan mereka kepada petugas DPU yang beroperasi setiap hari pada pagi hari untuk mengangkut sampah dagangan mereka ke Tempat Pembuangan sampah Sementara (TPS). Selain menghemat waktu, para pedagang juga dapat menghemat kantong dalam biaya pengangkutan sampah karena petugas yang mengangkut sampah tersebut dengan gerobak yang disediakan oleh DPU juga digaji sepenuhnya oleh DPU. Oleh sebab itu, untuk kawasan perdagangan dan jasa di Kupang Kidul memiliki konseptor hanya bertugas untuk mengarahkan bagaimana pengelolaan sampah dari hasil dagangan mereka.

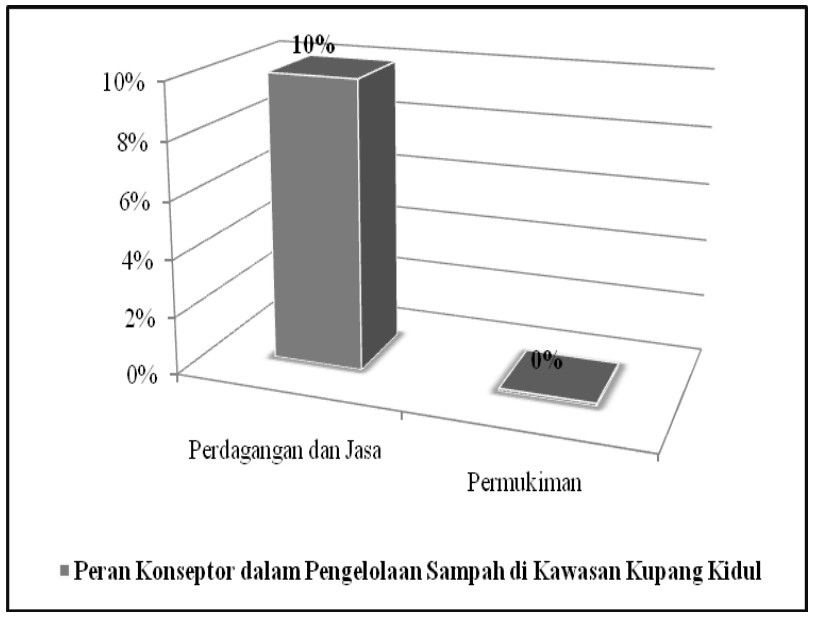

\section{Gambar 7. Hasil Skor Peran Konseptor dalam Pengelolaan Sampah di Kawasan Kupang Kidul}

Kuesioner check list digunakan sebagai instrument pengumpulan data untuk mengetahui seberapa besar peran masyarakat dalam pengelolaan sampah perkotaan baik 
pada kawasan permukiman maupun perdagangan dan jasa. Dari hasil perhitungan analisis skoring diperoleh nilai skor untuk peran konseptor di kawasan perdagangan dan jasa Kupang Kidul hanya sebesar 10\% artinya pada kawasan perdagangan dan jasa di Kupang Kidul terdapat aktor yang berperan sebagai konseptor dalam pengelolaan sampah hasilhasil dagangan baik pedagang dengan dagangan besar, sedang, dan kecil. Peran aktor tersebut mempengaruhi pengelolaan sampah yang ada di kawasan tersebut. Lain halnya dengan kawasan permukiman yang ada di Kupang Kidul, diperoleh skor sebesar 0\% artinya sangat jelas yaitu tidak ada peran konseptor yang dipercayakan untuk pengelolaan sampah dari masing-masing rumah tangga. Perbandingan peran konseptor dari kedua kawasan di Kupang Kidul diperlihatkan secara visualisasi pada Gambar 7.

Peran konseptor tidak sepenuhnya diperoleh dari masyarakat, namun ada pihak yang merasa memiliki tanggung jawab untuk mengelola sampah meskipun dalam skala kecil yaitu skala rumah tangga. Pihak tersebut dinamakan swasta. Dalam hal ini pihak swasta yang dimaksud lebih kepada perseorangan yang ingin membagi ilmunya dan meningkatkan taraf hidup masyarakat Kupang Kidul dengan keterampilan berbahan dasar murah yaitu sampah an-organik. Sejauh ini, beliau, Fauzan Latief, berencana membuat bank sampah untuk mengurangi tingginya volume sampah yang dihasilkan masing-masing rumah tangga. Selain itu, harapannya masyarakat dapat memperoleh keuntungan dari sampah yang pada dasarnya dianggap sudah tidak ada harga dan gunanya lagi.

Rencana baik ini sudah sampai pada tahap sosialiasi kepada masyarakat Kupang Kidul melalui organisasi masyarakat seperti ibu-ibu PKK dan perkumpulan remaja. Namun masih sedikit masyarakat Kupang Kidul yang tersentuh untuk berkomitmen dalam rencana pembuatan bank sampah ini dikarenakan pergerakan dari motor penggerak yaitu Bapak Fauzan Latief masih mengalami kendala dalam hal permodalan. Saat ini beliau sedang mencoba untuk mencari modal ke perusahaan-perusahaan yang dapat membantu mengaplikasikan ide dan impian beliau.

\section{Peran pada Level/ Aspek Pendanaan}

Pengelolaan sampah di kawasan Kupang Kidul tidak sepenuhnya menjadi tanggung jawab pemerintah. Masyarakat memiliki peran aktif dalam pengelolaan sampah termasuk dalam pendanaan. Secara umum, masyarakat di permukiman Kupang Kidul berkecimpung dengan adanya iuran yang dilakukan setiap bulannya untuk pengelolaan sampah di kawasan tersebut. Pengumpulan iuran tersebut biasanya dilakukan dalam skala RW ataupun RT.

Sebagian besar masyarakat tidak keberatan mengeluarkan sedikit biaya untuk sistem pengelolaan sampah di lingkungan tempat tinggalnya. Selain itu, masyarakat masih memiliki inisiatif untuk mengelola sampah skala mikro yaitu rumah tangga meskipun masih sampai pada tahap pewadahan dan pengumpulan serta pengangkutan sampai keTPS. Pengelolaan sampah yang ada di kawasan Kupang Kidul tidak terlepas dari peran pemimpin seperti ketua RT dan ketua RW. Mereka memiliki andil yang cukup besar untuk meneruskan regulasi di tingkat kecamatan untuk terus menjaga dan mengelola sampah yang dihasilkan oleh masing-masing rumah tangga. 


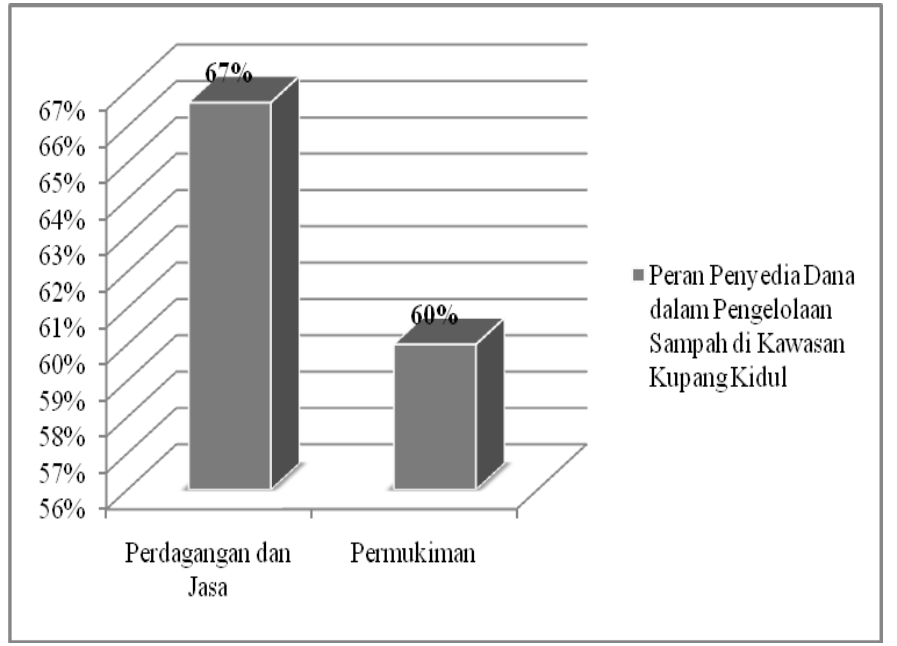

Gambar 8. Hasil Skor Peran Penyedia Dana dalam Pengelolaan Sampah di Kawasan Kupang Kidul

Gambar 8 menunjukkan bahwa tingginya peran masyarakat dalam hal pendanaan untuk pengelolaan sampah di kawasan Kupang Kidul. Untuk kawasan perdagangan dan jasa, peran masyarakat sebesar $67 \%$ artinya masyarakat berkecimpung melalui pembayaran iuran bulanan untuk pengelolaan sampah dimulai dari pengangkutan ke TPS dan ke TPA. Sedangkan untuk kawasan permukiman hanya sebesar $60 \%$ artinya sebagian besar masyarakat Kupang Kidul ikut berpartisipasi dalam pengelolaan sampah melalui iuran bulanan warga. Persentase peran masyarakat di kawasan permukiman lebih kecil karena sebagian kecil masyarakat lebih memilih untuk membuang sampah rumah tangga mereka ke TPS terdekat untuk sampah an-organik, sedangkan untuk sampah organik cenderung dibakar. Hal ini merupakan pola pemikiran yang masih salah dalam pengelolaan sampah.

\section{Peran pada Level/ Aspek Operasional}

Peran operasional dalam pengelolaan sampah di kawasan Kupang Kidul lebih cenderung diperankan langsung oleh masyarakat. Terbukti dimulai dari munculnya sampah yang diasumsikan masing-masing individu dapat menghasilkan sampah sebesar 3 liter/ hari. Apabila satu rumah tangga terdiri dari 4 orang maka jumlah sampah yang dihasilkan satu rumah tangga adalah sebesar 12 liter setiap harinya. Untuk itulah masyarakat mempunyai peranan penting dalam pengelolaan sampah yang berasal dari masing-masing individu dan rumah tangga. Kemudian sampah tersebut sampai kepada tahap pewadahan dan pengumpulan di masing-masing tempat pembuangan sampah. Kemudian mengalami transfer ke Tempat Pembuangan sampah Sementara (TPS) yang berada di dekat tempat bermukim masing-masing rumah tangga.

Sesampainya di TPS, sebagian besar peran masyarakat terhenti karena selanjutnya sampah dari TPS akan ditransfer ke Tempat Pembuangan Akhir (TPA) Blondo di Bawen. Pada tahap ini secara umum sudah menjadi tanggung jawab pemerintah daerah melalui Dinas DPU bidang Pengelolaan Persampahan. Untuk pengolahan sampah di TPA sepenuhnya menjadi tanggung jawab Dinas DPU. Siklus ini akan terus menerus berlangsung selama manusia masih memiliki kehidupan. Untuk itulah peran operasional dibutuhkan untuk mengelola sampah mulai dari timbul sampai hilang.

Kawasan Kupang Kidul yang terdiri dari campuran aktivitas baik permukiman maupun perdagangan dan jasa, membutuhkan peran operasional dalam pengelolaan 
sampah. Dari hasil observasi diperoleh bahwa terdapat peran masyarakat yang cukup besar dalam pengelolaan sampah di kawasan Kupang Kidul sebagai operasional.

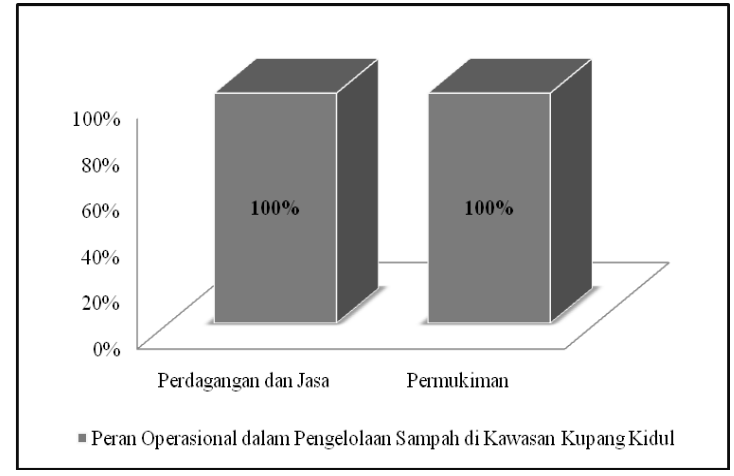

\section{Gambar 9. Hasil Skor Peran Operasional dalam Pengelolaan Sampah di Kawasan Kupang Kidul}

Dari Gambar 9 diperlihatkan bahwa skor yang diperoleh dari hasil observasi mengenai peran operasional masyarakat di kawasan Kupang Kidul baik permukiman maupun perdagangan dan jasa sama-sama sebesar 100\% artinya secara keseluruhan masyarakat yang ada di kawasan Kupang Kidul berperan langsung dalam pengelolaan sampah di tempat tinggal mereka baik secara langsung maupun tidak langsung. Pencapaian $100 \%$ ini memperlihatkan bahwa masyarakat di kawasan Kupang Kidul masih peduli terhadap lingkungan dan berusaha untuk tetap menjaga dan memelihara kelestarian lingkungan di kawasan Kupang Kidul.

\section{Temuan Penelitian}

Dari kedua gabungan aktivitas yang ada di kawasan Kupang Kidul yaitu permukiman dan perdagangan dan jasa dapat dilihat keterkaitan antaraktor yang terlibat dalam pengelolaan sampah di kawasan tersebut. Keterkaitan tersebut juga dapat digunakan sebagai pembanding seberapa besar peran yang dilakukan oleh masing-masing aktor dalam pengelolaan sampah yang ada di kawasan Kupang Kidul seperti yang divisualisasikan pada Gambar 10.

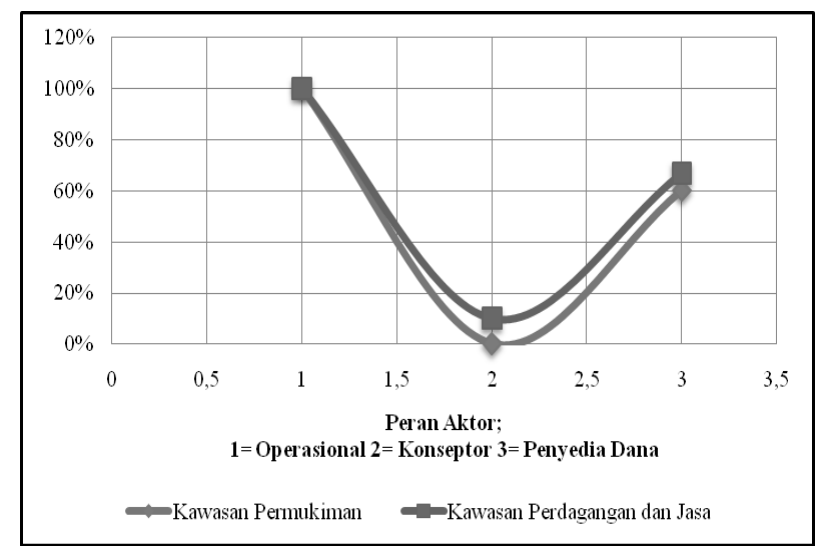

\section{Gambar 10. Hubungan Antaraktor dalam Pengelolaan Sampah di Kawasan Kupang Kidul}


Dari Gambar 10 dijelaskan bahwa terdapat perbedaan persentase keterlibatan aktor dalam pengelolaan sampah di kawasan Kupang Kidul. Dari kedua tata guna lahan yang berbeda yaitu permukiman dan perdagangan dan jasa, didominasi oleh peran aktor pada level operasional yaitu masyarakat dan swasta. Beda halnya dengan peran aktor sebagai penyedia dana. Hal ini dibuktikan bahwa belum semua masyarakat dan swasta mau dan ingin berpartisipasi dalam pengelolaan sampah pada level pendanaan. Untuk skala rumah tangga, masyarakat sudah mulai berpasrtisipasi dalam iuran untuk pengelolaan sampah di kawasan permukiman, namun tidak lebih besar pada kawasan perdagangan dan jasa.

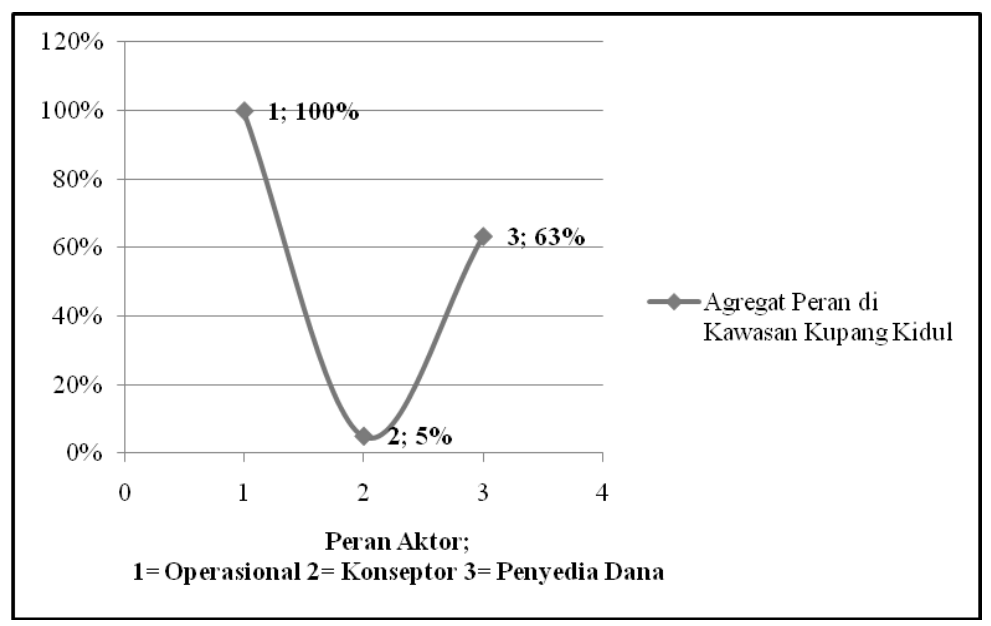

\section{Gambar 11. Kurva Agregat Peran Aktor dalam Pengelolaan Sampah di Kawasan Kupang Kidul}

Dari keseluruhan analisis bagaimana peran aktor dalam pengelolaan sampah di kawasan Kupang Kidul yang terdiri dari berbagai aktivitas dapat diambil generalisasi bahwa peran masyarakat dan swasta memiliki persentase yang berbeda dalam implementasinya. Untuk peran operasional memiliki persentase sebesar $100 \%$ artinya peran masyarakat dan swasta sebagai operasional mempunyai pengaruh yang cukup besar dalam pengelolaan sampah di kawasan tersebut. Perbedaan yang cukup signifikan terjadi pada peran konseptor yaitu sebesar 5\%. Persentase ini merupakan persentase terkecil dari ketiga peran lainnya. Namun, terjadi peningkatan yang cukup drastis pada peran masyarakat dan swasta pada level penyedia dana yaitu sebesar $63 \%$. Secara visualisasi, kurva agregat ketiga peran aktor dalam pengelolaan sampah di kawasan Kupang Kidul ditampilkan pada Gambar 11.

Secara keseluruhan peran aktor yang ada di kawasan Kupang Kidul yaitu masyarakat dan swasta, tidak terlepas juga peran pemerintah sebagai regulator yang mengeluarkan kebijakan terkait pengelolaan sampah di Kota Ambarawa. Di samping itu, sebagian besar masyarakat awam memiliki keyakinan buta bahwa sektor swasta harus selalu lebih efisien, hal ini berguna untuk memahami alasan mengapa sektor swasta dapat lebih efisien daripada sektor publik.

\section{Kesimpulan dan Rekomendasi}

Kupang Kidul merupakan salah satu kampung yang berada di RW VIII Desa Kupang, Kota Ambarawa. Kupang Kidul terdiri dari 8 RT dengan jumlah penduduk \pm 600 KK. Masyarakat Kupang Kidul memiliki budaya kerja bakti minimal 2x dalam sebulan. Biasanya kerja bakti 
dilakukan untuk pembersihan makam yang ada di lingkungan Kupang Kidul. Hal ini dilakukan sekaligus untuk mempererat hubungan antarwarga dengan jumlah penduduk yang sangat banyak sekaligus membiasakan pola hidup bersih dan sehat.

Peran masyarakat dan swasta dalam pengelolaan sampah skala perkotaan merupakan salah satu aspek penting yang harus ditingkatkan untuk pencapaian pengelolaan yang lebih maksimal. Dalam kaitannya dengan penelitian mengenai peran masyarakat dan swasta dalam pengelolaan sampah di kawasan Kupang Kidul, peran masyarakat dan swasta dibedakan menjadi tiga variabel yang berbeda yaitu konseptor, penyedia dana, dan operasional. Ketiga variabel ini mempunyai fungsi yang berbeda dalam pelaksanaannya, namun ada kalanya beberapa peran tergabung menjadi satu. Hal ini dapat disebabkan karena keberadaan masyarakat yang dapat memiliki peran di luar masyarakat itu sendiri.

Dari keseluruhan peran masyarakat dan swasta terkait pengelolaan sampah di kawasan Kupang Kidul yang terdiri dari berbagai aktivitas yaitu dominansi permukiman dan perdagangan dan jasa diketahui bagaimana dan seberapa besar persentase peran aktor sebagai konseptor, penyedia dana, dan operasional. Untuk peran konseptor memiliki persentase sebesar $60 \%$ artinya peran masyarakat dan swasta sebagai konseptor mempunyai pengaruh yang cukup besar dalam pengelolaan sampah di kawasan tersebut. Perbedaan yang cukup signifikan terjadi pada peran pendanaan yaitu hanya sebesar $3 \%$. Persentase ini merupakan persentase terkecil dari ketiga peran lainnya. Namun, terjadi peningkatan yang cukup drastis pada peran masyarakat dan swasta pada level operasional yaitu sebesar 38\%. Perbedaan persentase peran aktor yang terlibat dalam pegelolaan sampah di kawasan Kupang Kidul dikarenakan masih terbatasnya masyarakat dan swasta yang ikut serta dan berkecimpung langsung dalam pengelolaan sampah di kawasan tersebut. Hal ini berpengaruh besar terhadap keberhasilan pengelolaan sampah di tingkat perkotaan yaitu Kota Ambarawa.

Selain pemerintah, masyarakat, dan swasta yang menjadi aktor dalam pengelolaan sampah perkotaan di Ambarawa masih terdapat aktor yang berperan di luar aktor-aktor tersebut yang ikut berperan yaitu pemulung dan pengepul. Sebagian besar pemulung bukan berasal dari masyarakat Kupang Kidul dan menjadikan pemulung sebagai mata pencaharian mereka.

Swasta merupakan salah satu aktor yang memiliki peran dalam pengelolaan sampah di kawasan Kupang Kidul di luar peran pemerintah sebagai regulator. Sejauh ini peran swasta yang ada di kawasan Kupang Kidul terkait pengelolaan sampah masih digeluti oleh perorangan. Harapannya keterlibatan swasta ini dapat menjadi salah satu cara untuk meningkatkan kesadaran masyarakat untuk semakin terus dan terus memelihara lingkungan dengan cara mengelola sampah dalam skala mikro yaitu skala rumah tangga. Selain itu, diharapkan kepada petinggi di tingkat kelurahan untuk lebih menghimbau masyarakat di kawasan Kupang Kidul untuk mengelola sampah guna menjaga dan melestarikan lingkungan tempat tinggal dan sekitarnya. Salah satunya adalah untuk tidak lagi membuang sampah di sungai karena akibat yang ditimbulkan suatu saat akan menjadi bencana.

Penyelesaian permasalahan persampahan di masa depan yang mungkin lebih komplikasi harus cenderung menyesuaikan tujuan dan memperluas model yang diusulkan untuk memungkinkan menyertakan mengenai representasi analisis dampak lingkungan (polusi udara, dampak lalu lintas kota, dll). Perkembangan lain yang mungkin terjadi adalah analisis biaya daur ulang, transportasi, dan pemeliharaan misalnya, menyederhanakan asumsi bahwa biaya tersebut linear dalam siklusnya.

Dengan melakukan peninjuan beberapa aspek di atas, dapat disimpulkan perlunya suatu rencana tindak (action plan) yang meliputi: 


\section{Peran Masyarakat dan Swasta dalam Pengelolaan Sampah di Kota Kecil Jawa Tengah}

1. melakukan pengenalan karekteristik sampah dan metoda pembuangannya,

2. merencanakan dan menerapkan pengelolaan persampahan secara terpadu (pengumpulan, pengangkutan, dan pembuangan akhir),

3. menggalakkan program reduce, reuse dan recycle (3 R) agar dapat tercapai program zero waste pada masa mendatang,

4. mengembangkan teknologi pengelolaan sampah yang lebih bersahabat dengan lingkungan dan memberikan nilai tambah ekonomi bagi bahan buangan.

Keberhasilan rencana tindak tidak hanya dipengaruhi oleh aturan dan perundangundangan yang diterbitkan oleh pemerintah daerah. Sentuhan dan peran serta dari masyarakat dan swasta merupakan salah satu cara ampuh untuk mengatasi pengelolaan sampah yang masih amburadul. Kesadaran dan rasa tanggung jawab untuk menjaga dan merawat lingkungan merupakan faktor pendorong yang harus digalakkan dalam setiap individu. Dalam skala perencanaan, pengelolaan sampah yang tidak dikendalikan mulai dari saat ini akan berdampak pada generasi kota berikutnya di masa depan.

\section{Daftar Pustaka}

Alexander, Robby. 2007. Urbanisasi dan Perkembangan Perkotaan di Indonesia. Available at: http://robbyalexandersirait.wordpress.com/2007/10/05/urbanisasi-mobilitas-dan-perkembanganperkotaan-di-indonesia/. Diakses Rabu, 2 Mei 2012.

America's National Council on Public Private Partnership (http://www.NCPPP.org)

Asy’ari, Imam Sapari. 1993. Sosiologi Kota dan Desa. Surabaya: Penerbit Usaha Nasional.

Badan Pusat Statistik. 2010. Kecamatan Ambarawa dalam Angka 2006-2010. Semarang: Kantor BPS.

Bintarto. 1983. Interaksi Kota-Desa dan Permasalahannya. Yogyakarta: Gajahmada University Press.

Bult-Spiering, M. \& Dewulf, G. 2006. Strategic Issues in Public-Private Partnerships: An International Perspective. Blackwell Publishing Ltd, Oxford.

Cointreau, Sandra. 1994. Private Sector Partisipation in Municipal Solid Waste Services in Developing Countries. Washington D.C: Urban Management Programme

Daldjoeni. 1992. Seluk Beluk Masyarakat Kota. Bandung: Penerbit Alumni.

Daniels P.W. and Warness A.M. 1980. Movement In Cities: Spatial Perspective on Urban Transport and Travel. London: Methuen.

Emry, Hugh dan Trist, Evan. 1992. Rural Urban Linkages: Operasional Implications For Self-Sustainable Development. USA: PROP.

Jayadinata, Johara. 1986. Tata Guna Tanah dalam Perencanaan Pedesaan Perkotaan dan Wilayah. Bandung: Penerbit ITB.

Kecamatan Ambarawa dalam Angka Tahun 2007. Kantor BPS Jawa Tengah, 2007.

Kecamatan Ambarawa dalam Angka Tahun 2009. Kantor BPS Jawa Tengah, 2009.

Kecamatan Ambarawa dalam Angka Tahun 2011. Kantor BPS Jawa Tengah, 2011.

Kecamatan Ambarawa dalam Angka Tahun 2012. Kantor BPS Jawa Tengah, 2012.

Kurniawan. 2010. Pengelolaan Sampah di Indonesia. Available at: http://www.iec.co.id/berita/pengelolaansampah-di-indonesia. Diakses Rabu, 30 Mei 2012 jam 1:29.

Miller, J.B. 2000. Priciples of Public and Private Infrastructure Delivery. Boston: Kluwer Academic Publishers

Nazir, Moh. 2006. Metode Penelitian. Jakarta: Ghalia Indonesia.

Nurcahyo, Eko. 2012. Analisis Deskriptif Juga Ampuh. Available at: http://id.shvoong.com/exactsciences/statistics/2259090-analisis-deskriptif-juga-ampuh/\#ixzz1wHlnnsMs. Diakses Rabu, 30 Mei 2012 jam 1:43. 
Nurcholis, Ahmad. 2008. Karakteristik Struktur Ruang Internal Kota Delanggu Sebagai Kota Kecil di Koridor Surakarta-Yogyakarta, Tugas Akhir Tidak Diterbitkan, Program Studi Perencanaan Wilayah dan Kota, Fakultas Teknik Universitas Diponegoro, Semarang.

Prakash, Mathur Om. 1982. Small Cities and National Development. Nagoya: United Nations Centre for Regional Development.

Prihantini. 2007. Kecenderungan Urbanisasi Pada Kota Kecil Sokaraja dan Patikraja dalam Konteks Perkembangan Kota Purwokerto, Tugas Akhir Tidak Diterbitkan, Program Studi Perencanaan Wilayah dan Kota, Fakultas Teknik Universitas Diponegoro, Semarang.

Rencana Dasar Tata Ruang Kota Ambarawa 2007-2027. Badan Perencanaan Pembangunan Daerah Kota Ambarawa, 2006.

Rondinelli, Dennis A. 1983. Secondary Cities in Developing Countries. London: Sage Publisher.

Santoso, U. 1987. Limbah Bahan Ransum Unggas yang Rasional. Jakarta: Bhratara Karya Aksara.

Semarang Solid Wate Management Plan. Prepared for the city of Semarang by local consultants. 1991

Slamet. J.S. 2002. Kesehatan Lingkungan. Yogyakarta: Gajahmada University Press.

Sugiyono. 2009. Metode Penelitian Kuantitatif, Kualitatif dan R\&D. Bandung. Alfabeta.

Sundayani, Renny. 2011. 2 Faktor Utama Pemicu Urbanisasi. Available at: http://nasional.inilah.com/read/detail/1772900/2-faktor-utama-pemicu-urbanisasi. Diakses pada Rabu, 2 Mei 2012.

Standar Nasional Indonesia 19-2454-2002 tentang Tata Cara Teknis Operasional Pengelolaan Sampah Perkotaan, Badan Standar Nasional (BSN).

Umar, Ibnu. 2009. Pengelolaan Sampah Secara Terpadu di Wilayah Perkotaan. Available at: http://uwityangyoyo.wordpress.com/2009/04/05/pengelolaan-sampah-secara-terpadu-di-wilayahperkotaan/. Diakses 20 April 2012.

Undang-Undang RI No 26 tahun 2007 tentang Penataan Ruang. Jakarta: DPU, 2007.

Urbanisasi Berdampak Positif dan Negatif. [Home page of GEMARI] [Online]. Available at: http://www.gemari.or.id/file/edisi79/gemari7936.PDF. Diakses Rabu, 2 Mei 2012.

Urbanisasi. [Home page of WIKIPEDIA] [Online]. Available at: http://id.wikipedia.org/wiki/Urbanisasi. Diakses Rabu, 2 Mei 2012.

www.googleearth.com (Website Foto Udara Resmi Seluruh Dunia). Diakses 20 Mei 2012.

www.menlh.go.id (Official Website Menteri Lingkungan Hidup Indonesia). Diakses 18 Mei 2012. 
244 Peran Masyarakat dan Swasta dalam Pengelolaan Sampah di Kota Kecil Jawa Tengah

JURNAL WILAYAH DAN LINGKUNGAN, 1 (3), 223-240 